\title{
RELATIONS BETWEEN GLOBAL CITY CONNECTIVITY OF THE PRIMARY CITY AND THE SIZE NATIONAL ECONOMY
}

\author{
Yongling YAO ${ }^{1}$, Yongmei $\mathbf{L U}^{2}$, Gan WANG ${ }^{1}$, Yue DONG ${ }^{1}$, Haowei WANG ${ }^{1}$ \\ ${ }^{1}$ Renmin University of China, ${ }^{2}$ Texas State University, USA
}

\begin{abstract}
Some scholars emphasize the global cities network and suggest the declining of the national power. On the contrary, many studies insist on the role of the national economy on global cities. However, there is no specific model to show this relation and no evidence to conform which factor at national level impact this connectivity. The aim of this paper is to set up a specific model to illustrate the relationship between the national economic size and global cities connectivity, and to find the factor at national level impacting on world city connectivity. Bootstrap regression is adopted to set up the model for the relation. The results reveal that the national economic size has significant effectiveness on the global city connectivity with logarithmic function. This finding gives an explicit approach to clarify the idea of 'glocal' states with the combination of global city connectivity and national urban system.
\end{abstract}

Key Words: city interlock connectivity, global city, national economy, second nature of cities

\section{Introduction}

A city has two natures. The first nature is the urban place which is defined by the national urban system modelled as urban hierarchies; the second one is defined by the urban network by Taylor and Derudder (2016). As Gottman (1989) declared, the majority of the sustainable cities tend to rely more on the networks with other cities than the relationship they share with their hinterlands or service regions. A rising 'network society' by Castells (1996) also suggests that information flows are becoming much more crucial than places. However, there is little about the factors that contribute to and sustain the external relations of cities; in other words, what are the factors on which the connectivity between and among cities depend? Similarly, to understand the flowing space within cities, one need to know what elements are flowing among cities and what factors impact the sizes and directions of the flowing elements.

In practice, experiences show that global cities not only connect each other but also have relations with their hinterlands (Short 2017). The world city literature has noticed a weakened linkage between a state-centric world system and the cities within it, however these studies did not give the specific relation model even failed to clarify the factors linking them. Then, they failed to interpret the reasons for the location of Advanced Producer Service (APS) firms. These firms, as banking, diversified financials, health care, insurance, telecommunication and internet service sectors, have a crucial role in enabling economic globalization with their clients locating at the host countries. In order to accurately give reasons for the location of corporate headquarters in the city, it is necessary to find the specific relation and the factor at national level affecting the global city connectivity.

This paper takes the view that the role of the nation is still relevant in the formation of a city's connections to other cities. With the typical fitting curves from the national economic size and the interlock connectivity of their primate cities among these countries, the aim of this paper is to set up a specific model to illustrate the relationship between the national economy and the 
global cities connectivity and to find the factor at national level having effectiveness on world city connectivity. With this model, the evolution trajectory of the national economic size impacting on their primate city connectivity can be tracked with different countries. This result will help to interpret the formation of the world city system with the two dimensions of the national urban hierarchies (the first nature of a city) and the global city networks (the second nature of a city).

\section{Literature review}

As the global city network has been emphasized, some scholars suggest the declining of the national power. Meanwhile, many studies insist on the role of the national economy on global cities and their network with complicated ways. Brenner (1998) regards the territorial state as the 'glocal' state; Taylor (2002) suggested that world cities' national identities are enforced by incorporating their local and regional hinterlands, termed as 'hinter world', to provide new services across the world. Then, Cabigon (2006) confirms that the scale of a city's extending space determines a city position as being the center of a region; Therborn (2011) still argued the importance of the national economy on the global city. Even, the world city hypothesis by Friedmann (1986) has also indicated that the spatial distribution of labor at the global scale contributes to the formation of global cities, and it implies a new global urban hierarchy based on new labor divisions in the world system; as well as within the global cities trilogy by Sassen (1991), world cities are treated as the command centers, key locations, sites of production and innovation, and markets for the leading sector production. However, these studies failed to conduct a categorical interaction between the world city connectivity and their national economy by the absence of a specific model to show this relation. This local-global positioning is closely linked to the economic, social, political and cultural networks that support the organization of cities (Pflieger and Rozenblat 2010). Even though it seems risky to claim countries as spatial actors controlling the global economy (Faulconbridge 2007), urban systems and global systems are related to each other, and this relationship is yet to be studied further (Taylor 2014). Timberlake et al. (2012) conducted some evidence that global centrality increases income polarization with the mix of high level and low level of immigration and it suggested the need for further research for these relations. In terms of national urban hierarchies as vertical links which represent the national hinterland, and global city connectivity as horizontal links which represent the globalization, the authors of this paper insist that the formation of the world city system is determined by the two dimensions of hierarchies (vertical links) and by globalization (horizontal links) (Timberlake et al. 2012). This paper tries to set up a specific model to illustrate the relation between the global city connectivity of the primate city and the national economic size in order to combine the vertical and horizontal linkages together.

Some of the world city studies have tried to find the relationship between world cities and their locations. Grubesic et al. (2009) analyzed the distribution of the global airport hierarchies and it found that airline routes depend on the global or domestic economic conditions and the regional demand. The results of Musil (2014) show the correlation between the European global cities and the national scale depending on the capital and the statehood of the territory. Parnreiter (2014) argued that city connections should depend on the demand-supply relationships while demand is from the global city connection and the supply obviously denotes the hinterland of the city. The findings of Meijers et al. (2016) also show the significant determinants of metropolitan functions which present global city connectivity. Raźniak et al. (2015) find that the rank of global city connects with the economic potentiality of the host country but without the details. Belderbos et al. (2017) insisted on the hub function of global cities on flow of capital, people, ideas, etc. It is obvious that these studies do not confirm yet which factors impact the city connectivity at national level. Smith (2014) argued that the global city is the requirement for the global economy and not the vice versa; due to the lack of convincing empirical evidence for this relation, the global economy is subject to 'command' and 
it has been thrown into doubt. Dempsey (2016) suggested further investigation for the relation between global cities and the national economy. Derudder and Taylor (2017) explained the connections beyond hinterlands by the central flow theory but they failed to give the reasons for the various situations of other cities across urban places. Obviously, these results are various and indeterminate primarily because there is no specific factor at national level being involved. In order to interpret how and why the relation is within different countries, this paper tries to find what is the economic factor at national level that impacts the city connectivity by comparing effectiveness from variables of economic size and richness.

Among the empirical studies offering explanations for the world cities' connectivity, Taylor and Aranya (2008) tested a number of hypotheses regarding the change of city connectivity in the period 2000-2004. Their regression analysis was revealed to be significant at a very low confidence level and this may have resulted from mixing the factors of country and city levels together and by confusing the causality between the national economy and city connectivity. After devel-oping an alternative measurement by taking into account both possible underestimation and conceptual problems, Derudder et al. (2010) found that Shanghai and Beijing have witnessed the most substantial connectivity in the period 2000-2008, supporting the idea that the regional economic size impacts the major cities' connectivity. However, it remains difficult to justify the view that a country's economy impacts its city connectivity at different periods of national economic development because a relatively small number of situations have been studied. As pointed out by Taylor (2014), limited empirical findings exist to explain the formation of economic actors and their practices on global cities and the world city network. In order to get complete understanding about the relation track among different countries, this paper tries to untangle the impacts with cross section data to simulating the relation track.

In view of the above, we examine the relationship between a global city's connectivity and its national economy by following the definition of the city interlock connectivity suggested by Taylor and Derudder (2016). The data from the international APS corporations in the primate cities and their national GDP were used to match the city and the corresponding hinterland so as to combine the vertical and horizontal linkages into the network. Due to the fact that the number of the involved countries is small as statistic sample, the Bootstrap method was adopted to estimate the parameters and to test the validity for the models. The significant model confirms the factor (GDP size, e.g.) at national level having effectiveness on city connectivity. The estimated model and the fitting curve can be employed to explain the formation of world city and the network and to answer the questions about the periodically 'curved' or 'flatter' world.

\section{Methodology}

Investigating the relationship between the primate global city connectivity and the national economy

Jacobs' (1984) Dynamic City Theory argues for five great economic forces acting in the city expansion, namely: new market, new employment, relocation, new technology and new capital. The increases in market, jobs, technology, inflow industries and capital can create a mix of opportunities for a city that lead to the diffusion of the city's economy; but these increases are inseparable from the economic landscape in which the city exists; ultimately, cities cannot be understood without exploring their relations with the countries (Jacobs 1992). Thus, within a national urban system, the primate city is always expressive of the national capacity and it is the national focal-point; the second and subsequently smaller cities are the hinterlands orderly. Within globalization, the city connection is beyond the national connection. Nevertheless, the 'flow space' still depends on the business distribution of cross-country firms. When the connection is calculated by APS firms, the causality between the national economy and the 
primate city connectivity is explained in Fig. 1.

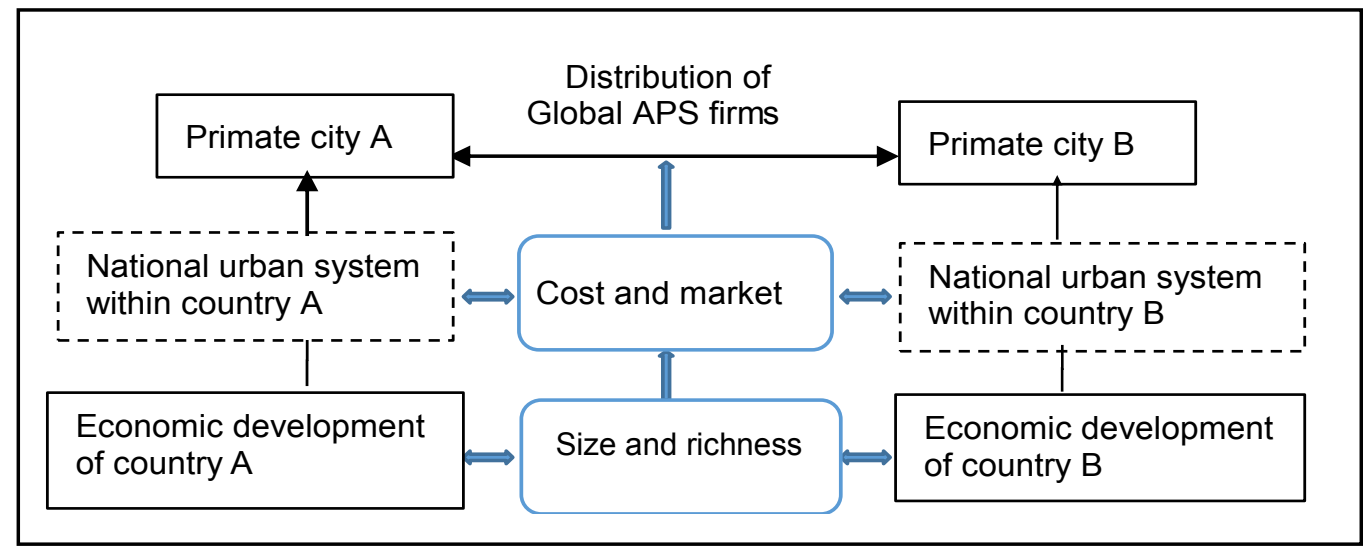

Fig. 1 - The causal relationship between global city connectivity and the national economy

Source: The authors

Fig. 1 indicates that the first nature of a city is intrinsic to the physical site itself. The second nature is determined by the extent of development of that location, here the country (e.g. the availability of suppliers) based on the spatial structure of the global economic system (e.g. the benefits of services access to a large market). Thus, the primate city depends on the national urban system with which the second and subsequently smaller cities are organized within the country, and it is finally determined by the market size which corresponds to the economic development of the country. As a result, the authors assume that the national economic size effects on the national urban system and then on the city connectivity, as well as the location of a city, reflect the strength of the nation within which it is embedded. The relation between the primate city connectivity and the national economy is the combination of the horizontal link and the vertical link of the two urban systems. It is nonetheless necessary to clarify the specific effects so as to better define the impact models.

\section{Calculating the city interlock connectivity}

Three types of network measurement can be found in the literature to quantify city connectivity, including airline passengers (Keeling 1995, Rimmer 1998, O'Connor 2003, Matsumoto 2004, Smith and Timberlake 1995, 2001, 2002, Derudder and Witlox 2005, 2008, Mahutga et al. 2010, Ordóñez and García 2010, Pirie 2010, Ma and Timberlake 2013), internet backbone (Beaverstock et al. 2000, Moss and Townsend 2000, Townsend 2001a and 2001b, Malecki 2002, Choi et al. 2006), and distribution of APS firms and branches (Derudder et al. 2003, Alderson et al. 2010, Van Oort et al. 2010, Jacobs et al. 2011, Musil 2013, Taylor et al. 2014). Different types of measurements reveal various aspects of global linkages. While airline passenger data reflect travel volumes across the world, air travel trips are impacted by distance (Choi et al. 2006, Hermelin 2009). The linkage by the internet backbone infrastructure is heavily impacted by accessibility - referred to as a 'digital gap' - and it overlooks the marketing size of global businesses. The linkages between affiliated offices, vital strategic information and knowledge - needed for the co-ordination of business - flow between cities. Therefore, the distribution of APS firms and branches has been used as an indicator for city interlock connectivity in this paper. 
Following Taylor and Derudder (2016), city interlock connectivity in this paper can be calculated as follows:

$$
\begin{aligned}
& r_{a b}=\sum_{j} r_{a b j} \\
& N_{a}=\sum_{i} r_{a i}, a \neq j \\
& T=\sum_{i} N_{a} \\
& L_{n}=\left(N_{n} / T\right)
\end{aligned}
$$

Where $r_{a b j}$ represents the relation between city $a$ and city $b$ when evaluated by firm j; $r_{a b}$ represents the relation between these two cities when considering all firms, $N_{a}$ indicates the interlock connectivity of city a in the network and $T$ is the total network interlock connectivity; $L_{n}$ represents the proportion of city a's interlock connectivity in the whole city network; it is a standardized measure of the interlock connectivity of city $a$ in the city network and it is used to describe city interlock connectivity for the analyses reported in the rest of this paper. These expressions indicate that when cities have been involved into the calculation, the interlock values are calculated among these cities.

\section{Data preparation}

As the world economy has advanced, economic growth has become increasingly dependent on the service sector. Based on a world city hypothesis by Friedman (1986) and Sassen (1991), world cities are taken as service centers for the global economy as represented by the presence of headquarters and branches operations, financial services, information and business services, knowledge flow, advanced technological and education activities, advanced logistics and trading, global cultural activities and creativities, etc. While world cities are denoted as prime centers for the production and consumption of business services in the organization of global capital, their connectivity is also based on a city's capability to generate strategic corporate information and knowledge flows through the presence of globalised APS firms. There is, though, a need for more knowledge about how service firms develop in global structures (Boussebaa 2009). Practical observation shows that APS firms play critical roles for employment, knowledge development, innovations, value added and export incomes in developed economies, where APS firms tend to be heavily concentrated in major urban and metropolitan regions (Hermelin 2009). APS firms have increasingly become multinational firms in an international market to service existing clients and to attract new ones (Aharoni and Nachum 2000, Harrington and Daniels 2006). They have further been identified as the network makers, since transnational companies (TNC) are the prime movers in the globalizing economy through their distribution functions. Transnational APS firms are therefore widely denoted as indicator for the world city connectivity.

Thus, APS firm's headquarters and their branch distribution networks are employed as an indicator for city connectivity in this paper. The global Fortune 500 companies are usually indicated as the mainstream of transnational firms. There were 156 and 250 advanced producer service (APS) firms in the list of Fortune 500, for July 2010 and 2016 respectively (banking, diversified financials, health care, insurance, telecommunication and internet service 
sectors). Among the 156 and 250 companies, 61 and 106 had headquarters plus branches listed on their websites, which were distributed among 49 and 59 cities around the world in 2010 and 2016 respectively (see Appendix $\mathrm{I}^{1}$ ). The matrix values $L_{n}$ for city interlock connectivity have been calculated based on the numbers of headquarters and branches of these companies in each city among the 49 and 59 cities. The data source for the headquarters and branches distribution networks of each company is the company's website.

Following equation (4), the value of each city's interlock connectivity was calculated. Furthermore, in order to facilitate the examination of the relationship between each city and its country, only those cities that were ranked as the top in their country were kept for further analysis. Although some of these cities would not be considered 'world cities' (as defined), they have been included when transnational firms were operating there so as to connect the city with the global economy. As a result, among the universe of 49 and 59 cities, the values of 35 and 37 cities and 35 and 37 corresponding hosting countries in 2010 and 2016 respectively were valid and retained for the study.

There were 1278 and 2530 headquarters and branches distributed around the 35 and 37 cities in 2010 and 2016 respectively, which have been used to induce values of $L_{n}$ for the 35 and 37 cities. The data for each national economic size represented by the Gross Domestic Production (GDP) were extracted from the report of World Bank (2010 and 2016). Aggregated GDP, the chief national-level economic variable, was used to indicate the size of each national economy. In order to distinguish further the effects of country richness, the GDP per capita was also involved into the model. Table 1 gives the calculated city interlock connectivity for each city and the national GDP and GDP per capita for the corresponding host countries.

The cities, dependent variables, and independent variables

\begin{tabular}{|l|r|r|l|r|r|r|r|}
\hline \multicolumn{1}{|c|}{ City } & \multicolumn{2}{c|}{$\begin{array}{c}\text { City Interlock } \\
\text { connectivity (\%) }\end{array}$} & Country & \multicolumn{2}{c|}{$\begin{array}{c}\text { National GDP } \\
\text { (Million USD) }\end{array}$} & \multicolumn{2}{c|}{$\begin{array}{c}\text { National GDP/cap. } \\
\text { Capita (USD/ } \\
\text { person) }\end{array}$} \\
\hline & 2010 & 2016 & & 2010 & 2016 & 2010 & 2016 \\
\hline London & 4.1345 & 4.0837 & U.K. & 2174530 & 2618886 & 37840 & 39899 \\
\hline New York & 6.6187 & 3.1861 & USA & 14256300 & 18569100 & 48550 & 57467 \\
\hline Tokyo & 2.3179 & 4.3728 & Japan & 5067526 & 4939384 & 45130 & 38894 \\
\hline Paris & 3.7736 & 2.2871 & France & 2649490 & 2465454 & 42690 & 36855 \\
\hline Sydney & 1.9191 & 2.0097 & Australia & 924844 & 1204616 & 50120 & 49928 \\
\hline Milan & 1.9570 & 1.1257 & Italy & 2112780 & 1849970 & 35350 & 30527 \\
\hline Toronto & 1.5975 & 1.8304 & Canada & 1336067 & 1529760 & 46730 & 42158 \\
\hline Moscow & 0.8841 & 2.5599 & Russia & 1230726 & 1283162 & 10810 & 8748 \\
\hline Seoul & 1.1762 & 1.2043 & Korea & 832512 & 1411246 & 20870 & 27539 \\
\hline Frankfurt & 1.2998 & 1.1367 & Germany & 3346702 & 3466757 & 44230 & 41936 \\
\hline Brussels & 1.4339 & 1.6382 & Belgium & 468553 & 466366 & 45840 & 41096 \\
\hline Amsterdam & 0.4592 & 2.1338 & the Nether- & 792128 & 770845 & 49660 & 45295 \\
\hline Buenos Aires & 1.0189 & 1.3205 & Argentina & 308741 & 545866 & 10871 & 12449 \\
\hline
\end{tabular}

1) The other companies did not give any indication of their headquarters and branches locations. There are five levels of branches according to Taylor's definition, but we just selected the first level branches from the company's websites. Additionally, only the primary city in each country was considered. These choices did not, in our view, invalidate our results. All the branches are confirmed by checking the efficient telephone number and their active business at the end of 2010 and 2016 respectively. 
Relations between Global City Connectivity of the Primary City and the Size National Economy

\begin{tabular}{|c|c|c|c|c|c|c|c|}
\hline \multirow[t]{2}{*}{ City } & \multicolumn{2}{|c|}{$\begin{array}{c}\text { City Interlock } \\
\text { connectivity (\%) }\end{array}$} & \multirow[t]{2}{*}{ Country } & \multicolumn{2}{|c|}{$\begin{array}{l}\text { National GDP } \\
\text { (Million USD) }\end{array}$} & \multicolumn{2}{|c|}{$\begin{array}{l}\text { National GDP/cap. } \\
\text { Capita (USD/person) }\end{array}$} \\
\hline & 2010 & 2016 & & 2010 & 2016 & 2010 & 2016 \\
\hline Mumbai & 1.1663 & 2.1033 & India & 1310171 & 2263522 & 1450 & 1709 \\
\hline Sao Paulo & 1.1762 & 1.8746 & Brazil & 1571979 & 1796187 & 10700 & 8650 \\
\hline $\begin{array}{l}\text { Kuala } \\
\text { Lumpur }\end{array}$ & 0.9831 & 2.4488 & Malaysia & 191601 & 296359 & 8800 & 9503 \\
\hline Zurich & 10.9843 & 1.6122 & $\begin{array}{l}\text { Switzer- } \\
\text { land }\end{array}$ & 523772 & 659827 & 76350 & 78813 \\
\hline $\begin{array}{l}\text { Mexico } \\
\text { City }\end{array}$ & 0.6355 & 1.7583 & Mexico & 874902 & 1045998 & 8970 & 8201 \\
\hline Warsaw & 1.0779 & 1.8740 & Poland & 430076 & 469509 & 12330 & 12372 \\
\hline Jakarta & 1.4886 & 2.6417 & Indonesia & 540277 & 932259 & 2930 & 3570 \\
\hline Dublin & 1.6312 & 1.4953 & Ireland & 227193 & 294054 & 38960 & 61607 \\
\hline Bangkok & 1.3412 & 2.5865 & Thailand & 263856 & 406840 & 4620 & 5908 \\
\hline Stockholm & 0.6011 & 1.3803 & Sweden & 406072 & 511000 & 53530 & 51600 \\
\hline Istanbul & 0.5379 & 2.1143 & Turkey & 617099 & 857749 & 10510 & 10788 \\
\hline Prague & 0.2816 & 1.3946 & $\begin{array}{l}\text { Czech } \\
\text { Republic }\end{array}$ & 190274 & 192925 & 18720 & 18267 \\
\hline Lisbon & 0.2050 & 1.5615 & Portugal & 227676 & 204565 & 21420 & 19813 \\
\hline Vienna & 1.7435 & 0.9763 & Austria & 384909 & 386428 & 48170 & 44177 \\
\hline Budapest & 0.6214 & 1.5219 & Hungary & 128964 & 124343 & 12860 & 12665 \\
\hline Athens & 0.8876 & 1.2653 & Greece & 329924 & 194559 & 24490 & 18104 \\
\hline Caracas & 0.3244 & 0.5814 & Venezuela & 326498 & 371337 & 11760 & 9230 \\
\hline Auckland & 0.5884 & 1.4628 & $\begin{array}{l}\text { New } \\
\text { Zealand }\end{array}$ & 125160 & 185017 & 30620 & 39427 \\
\hline Santiago & 0.6994 & 1.2127 & Chile & 163670 & 247028 & 12270 & 13793 \\
\hline Beijing & 2.0012 & & China & 4984700 & & 4940 & \\
\hline Shanghai & & 3.7064 & China & & 11199145 & & 8123 \\
\hline Madrid & 2.1045 & & Spain & 1460250 & & 30930 & \\
\hline Barcelona & & 1.8298 & Spain & & 1232088 & & 26529 \\
\hline Singapore & 2.6472 & & Singapore & 182232 & & 45690 & \\
\hline Dubai & & 1.3400 & $\begin{array}{l}\text { The United } \\
\text { Arab } \\
\text { Emirates }\end{array}$ & & 348743 & & 37622 \\
\hline Manila & & 1.5362 & $\begin{array}{l}\text { The Philip- } \\
\text { pines }\end{array}$ & & 304905 & & 2951 \\
\hline $\begin{array}{l}\text { Ho Chi } \\
\text { Ming City }\end{array}$ & & 1.5576 & Vietnam & & 202616 & & 2186 \\
\hline Max. & 16.6187 & 4.3728 & & 14256300 & 18569100 & 76350 & 78813 \\
\hline Min. & 0.2050 & 0.5814 & & 125160 & 124343 & 1450 & 1709 \\
\hline Average & 1.5626 & 1.9115 & & 1451432.03 & 1779687 & 27991.74 & 26443.22 \\
\hline S.D. & 3.1374 & 0.8368 & & 2554422 & 3451856 & 19045.87 & 19720.92 \\
\hline
\end{tabular}

\section{Modeling the relationship}

The objective of this paper is to illustrate the curve of the two variables, the primate cities interlock connectivity and their national GDP, to find the track of this relation. There are two steps to model the relation.

The first step is to draw scatter plots with the values of interlock connectivity of the primate 
cities and their national GDP, GDP/cap., which were 35 dots in 2010 and 37 dots in 2016 (Fig. 2).

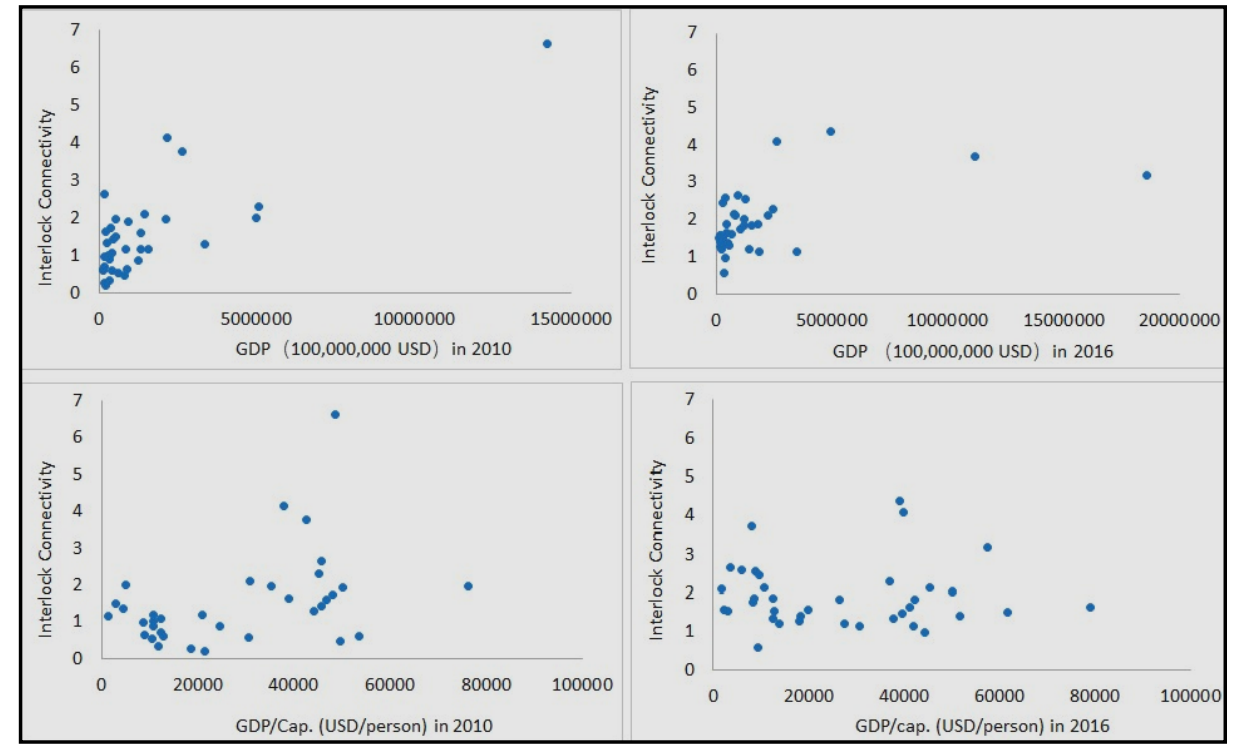

Fig. 2 - The values of interlock connectivity of the primate cities and their national GDP, GDP/cap.

The second step is to model the relations and to estimate parameters for the scatter plots. Due to the dull distribution of these dots, typical functions, such as linear, logarithmic, inverse, quadratic, cubic, power and exponential functions, will be adopted to estimate their parameters. With each model, there were fixed the parameters for the values of city interlock connectivity and GDP, GDP/cap. in 2010 and 2016 with regressions respectively. Bootstrap is a technique to expand the sample size by resampling it independently from the same data with OLS to meet the requirement of the regression. Owning to small sample size of data in each year, the nonparametric Bootstrap method is used to estimate the parameters for each function and to test the validity of the estimations comparing with the results of OLS (see Table 2 for the results of estimations with logarithmic and power functions) ${ }^{2}$.

\section{Results}

Table 2 shows that, with logarithmic and power functions, the parameters of variable GDP are all significant no matter if one or two variables are involved together, in 2010 or 2016 respectively. As well as the parameters about the constant variable show to be stable. However, the parameters of variable GDP/cap are significant only in 2010 but non-significant in 2016. These results denote that the GDP size has a stably significant impact on the primate city interlock connectivity as independent univariate; the richness of the national economy has not a stable impact on the city connectivity. The function about the relation between the global city connectivity of the primary city and the size national economy is equation (5) as the following:

2) Comparing all the results, except the logarithmic and power functions, too small coefficients in linear, inverse, quadratic, cubic and exponential functions, as well as the parameters of GDP, show no significance in 2016 with the latter models. Therefore, the results of logarithmic and power functions are listed in the text and the results for the other ones are listed in Appendix 2. 
Relations between Global City Connectivity of the Primary City and the Size National Economy

Results of estimations for logarithmic and power functions

Table 2

\begin{tabular}{|c|c|c|c|c|c|c|c|}
\hline \multirow{2}{*}{ Variables } & \multirow{2}{*}{ Year } & \multicolumn{2}{|c|}{ GDP } & \multicolumn{2}{|c|}{ GDP/cap } & \multicolumn{2}{|c|}{ GDP-GDP/cap } \\
\hline & & $\overline{\mathrm{OLS}}$ & Bootstrap & OLS & Bootstrap & OLS & $\begin{array}{l}\text { Boot- } \\
\text { strap }\end{array}$ \\
\hline \multicolumn{8}{|c|}{ Logarithmic function } \\
\hline \multirow[t]{2}{*}{ Ingdp } & 2010 & $\begin{array}{r}0.709^{* \star *} \\
(0.143) \\
\end{array}$ & $\begin{array}{r}0.709^{\star \star \star} \\
(0.234) \\
\end{array}$ & & & $\begin{array}{r}0.672^{* \star *} \\
(0.138) \\
\end{array}$ & $\begin{array}{r}0.672^{\star \star \star} \\
(0.212) \\
\end{array}$ \\
\hline & 2016 & $\begin{array}{l}0.443^{* * *} \\
(0.0943)\end{array}$ & $\begin{array}{r}0.443^{\star * *} \\
(0.115)\end{array}$ & & & $\begin{array}{l}0.458^{* * *} \\
(0.0956)\end{array}$ & $\begin{array}{l}0.458^{\star * *} \\
(0.0956)\end{array}$ \\
\hline \multirow[t]{2}{*}{ Ingdpp } & & & & $\begin{array}{l}0.451^{* *} \\
(0.219)\end{array}$ & $\begin{array}{l}0.451^{* *} \\
(0.226)\end{array}$ & $\begin{array}{r}0.342^{*} \\
(0.170)\end{array}$ & $\begin{array}{l}0.342^{* *} \\
(0.153)\end{array}$ \\
\hline & 2016 & & & $\begin{array}{r}-0.0254 \\
(0.142)\end{array}$ & $\begin{array}{r}-0.0254 \\
(0.124)\end{array}$ & $\begin{array}{l}-0.112 \\
(0.113)\end{array}$ & $\begin{array}{r}-0.112 \\
(0.0897) \\
\end{array}$ \\
\hline \multirow[t]{2}{*}{ Constant } & 2010 & $\begin{array}{r}-4.735^{\star * *} \\
(1.273)\end{array}$ & $\begin{array}{r}-4.735^{\star \star} \\
(1.983)\end{array}$ & $\begin{array}{l}-2.950 \\
(2.182)\end{array}$ & $\begin{array}{r}-2.950 \\
(2.158)\end{array}$ & $\begin{array}{r}-7.807^{* * *} \\
(1.953)\end{array}$ & $\begin{array}{r}-7.807^{* * *} \\
(2.541)\end{array}$ \\
\hline & 2016 & $\begin{array}{r}-2.053^{\star *} \\
(0.852) \\
\end{array}$ & $\begin{array}{r}-2.053^{* *} \\
(0.969) \\
\end{array}$ & $\begin{array}{r}2.161 \\
(1.403) \\
\end{array}$ & $\begin{array}{l}2.161^{*} \\
(1.187) \\
\end{array}$ & $\begin{array}{r}-1.091 \\
(1.293) \\
\end{array}$ & $\begin{array}{r}-1.091 \\
(1.436) \\
\end{array}$ \\
\hline \multirow[t]{2}{*}{$\begin{array}{l}\text { Observa- } \\
\text { tions }\end{array}$} & 2010 & 35 & 35 & 35 & 35 & 35 & 35 \\
\hline & 2016 & 37 & 37 & 37 & 37 & 37 & 37 \\
\hline \multirow[t]{2}{*}{ R-squared } & 2010 & 0.427 & 0.427 & 0.114 & 0.114 & 0.491 & 0.491 \\
\hline & 2016 & 0.386 & 0.386 & 0.001 & 0.001 & 0.403 & 0.403 \\
\hline \multicolumn{8}{|c|}{ Power function } \\
\hline \multirow[t]{2}{*}{ Ingdp } & 2010 & $\begin{array}{l}0.403^{\star * \star} \\
(0.0890)\end{array}$ & $\begin{array}{l}0.403^{\star \star *} \\
(0.0843)\end{array}$ & & & $\begin{array}{l}0.386^{* \star *} \\
(0.0884)\end{array}$ & $\begin{array}{l}0.386^{\star \star \star} \\
(0.0833)\end{array}$ \\
\hline & 2016 & $\begin{array}{l}0.195^{\star \star \star} \\
(0.0485)\end{array}$ & $\begin{array}{l}0.195^{\star \star \star} \\
(0.0477)\end{array}$ & & & $\begin{array}{l}0.204^{* \star *} \\
(0.0489)\end{array}$ & $\begin{array}{l}0.204^{\star * \star} \\
(0.0480)\end{array}$ \\
\hline \multirow[t]{2}{*}{ Ingdpp } & 2010 & & & $\begin{array}{r}0.220 \\
(0.134) \\
\end{array}$ & $\begin{array}{c}0.220^{*} \\
(0.124) \\
\end{array}$ & $\begin{array}{r}0.158 \\
(0.109) \\
\end{array}$ & $\begin{array}{r}0.158 \\
(0.112) \\
\end{array}$ \\
\hline & 2016 & & & $\begin{array}{c}-0.0264 \\
(0.0692)\end{array}$ & $\begin{array}{c}-0.0264 \\
(0.0615)\end{array}$ & $\begin{array}{r}-0.0649 \\
(0.0579)\end{array}$ & $\begin{array}{r}-0.0649 \\
(0.0445)\end{array}$ \\
\hline \multirow[t]{2}{*}{ Constant } & 2010 & $\begin{array}{r}-3.405^{\star \star \star} \\
(0.793) \\
\end{array}$ & $\begin{array}{r}-3.405^{\star * *} \\
(0.778) \\
\end{array}$ & $\begin{array}{r}-2.029 \\
(1.338) \\
\end{array}$ & $\begin{array}{l}-2.029^{*} \\
(1.224) \\
\end{array}$ & $\begin{array}{r}-4.819^{* \star \star} \\
(1.251) \\
\end{array}$ & $\begin{array}{r}-4.819^{\star * \star} \\
(1.253) \\
\end{array}$ \\
\hline & 2016 & $\begin{array}{r}-1.180^{\star *} \\
(0.438) \\
\end{array}$ & $\begin{array}{r}-1.180^{* * *} \\
(0.418) \\
\end{array}$ & $\begin{array}{r}0.825 \\
(0.682) \\
\end{array}$ & $\begin{array}{r}0.825 \\
(0.602) \\
\end{array}$ & $\begin{array}{r}-0.622 \\
(0.662) \\
\end{array}$ & $\begin{array}{r}-0.622 \\
(0.708) \\
\end{array}$ \\
\hline \multirow[t]{2}{*}{$\begin{array}{l}\text { Observa- } \\
\text { tions }\end{array}$} & 2010 & 35 & 35 & 35 & 35 & 35 & 35 \\
\hline & 2016 & 37 & 37 & 37 & 37 & 37 & 37 \\
\hline \multirow[t]{2}{*}{ R-squared } & 2010 & 0.383 & 0.383 & 0.075 & 0.075 & 0.421 & 0.421 \\
\hline & 2016 & 0.316 & 0.316 & 0.004 & 0.004 & 0.340 & 0.340 \\
\hline
\end{tabular}

Notes: (1) Standard errors in parentheses. ${ }^{* * *} p<0.01,{ }^{* *} p<0.05,{ }^{*} p<0.1$. (2) GDP indicates the estimation with GDP variable only; GDP/cap. indicates the estimation with GDP/cap only; GDP-GDP/cap indicates the estimation with both GDP and GDP/cap together. (3) New York has a high value of city connectivity in 2010 and it seems like a singular value. However, when the value of New York in 2010 is moved away, the results do not change anymore but the Adjusted $R$ square value is 0.459 , increasing with 0.076 compared with the ones of the total values involved.

$$
C n=\alpha+\beta \ln G D P
$$


Where $C n$ represents the city interlock connectivity, GDP represents the national GDP size. $\alpha$ and $\beta$ is constant respectively. The original formula can be a power function like:

$$
\mathrm{e}^{\mathrm{Cn}}=\mathrm{e}^{\alpha}+\mathrm{GDP}^{\beta}
$$

$$
\text { when } \quad \mathrm{e}^{\mathrm{Cn}}=\mathrm{f}(\mathrm{Cn}) \quad \text { then } \quad \mathrm{e}^{\alpha}=\alpha_{0} \quad \mathrm{f}(\mathrm{Cn})=\alpha_{0}+\mathrm{GDP}^{\beta}
$$

Factually, the power function is the transformation of logarithmic function. Thus, the relation between the city connectivity of the primary city and the size of their national economy is represented by the models of logarithmic function or power function. Furthermore, the values of adjusted R square about the independent variable GDP size for the logarithmic function are 0.427 and 0.386 in 2010 and 2016 respectively. The result indicates that the GDP size, as the independent univariate for the city interlock connectivity, can explain the effects of national economic size on city interlock connectivity at $42.7 \%$ and $38.6 \%$ levels respectively. The values of adjusted R square for the logarithmic function are 0.383 and 0.316 in 2010 and 2016 respectively. It indicates that the GDP can explain the effects at $38.3 \%$ and $31.6 \%$ levels respectively. Then, the logarithmic function is better than the power one because the parameters of logarithmic function are more efficient than the ones of power function. Finally, the results of logarithmic function are adopted to illustrate the relation between city interlock connectivity and national GDP size.

Combining the data about city interlock connectivity and national GDP size in 2010 and 2016 together, the curve of these two variables with logarithmic function is in Fig. 3.

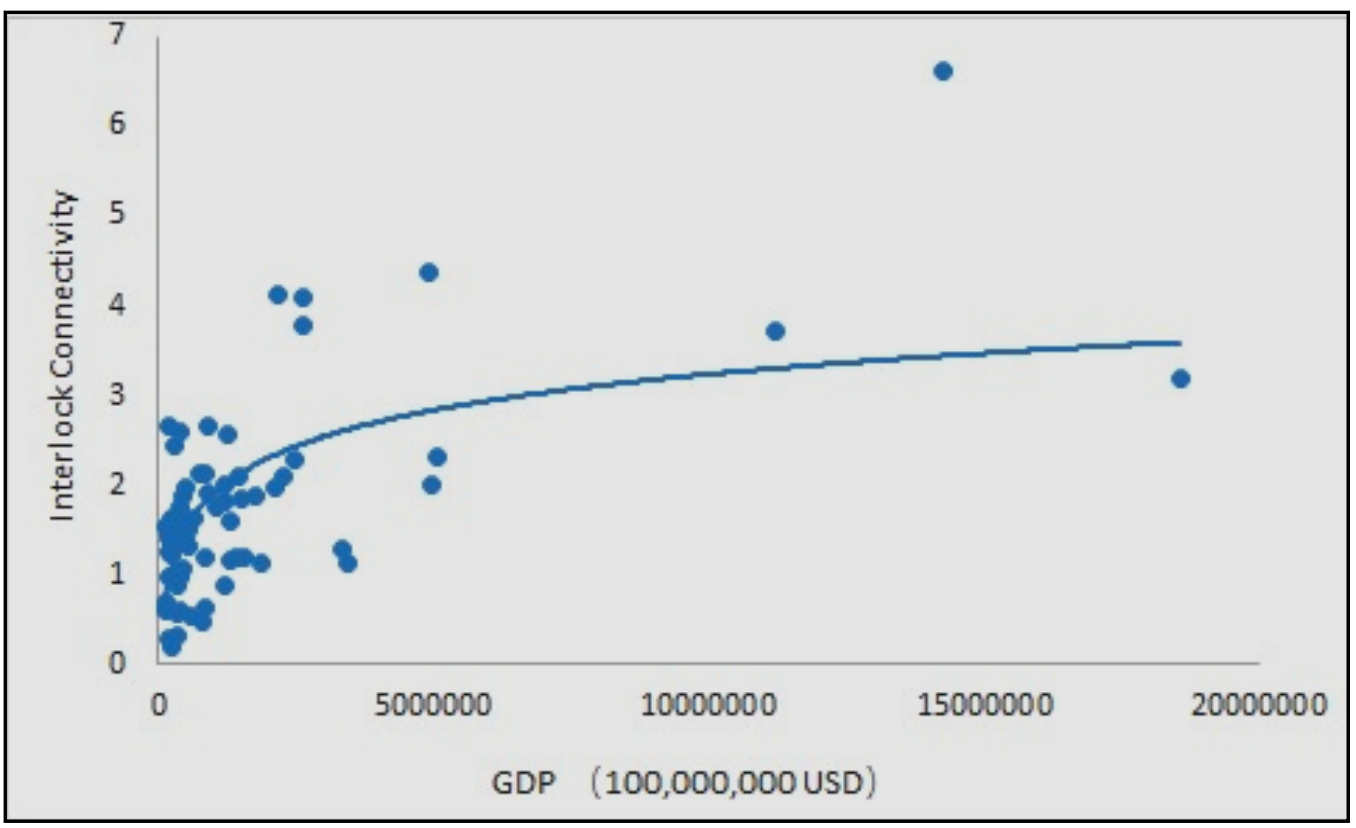

Fig. 3 - The relation between city interlock connectivity and national GDP with logarithmic function

The curve in Fig. 3 shows that the city connectivity increases with the national GDP size rising 
significantly at two different periods. At the primary period, the national GDP is approximately less than 500 trillion USD, the value increases rapidly and most the countries are at this period; at the second period, the national GDP is more than 500 trillion USD, the connectivity value increase smoothly and a few countries are at this period.

\section{Discussion}

The analysis reported above shows that national economies have significant effects on the city interlock connectivity of the primary city in a world cities network with logarithmic function. This provides empirical evidence that the world city system is related to the general structure of the global economic system. It reveals that the primary cities in all the core countries of the world system continue to benefit greatly from the growth in the national GDP; their economic growth is showing strong and positive effects on increasing the primary cities' connectivity in a world city network. With plenty of fully-fledged high-end service firms in these cities, the growth of a national economy goes together with the strengthening of the centrality of their primary cities.

The effectiveness of national GDP other than GDP/cap on the global city connectivity conducts that it is the national economic size which determines the market size and the density of economic activities rather than national richness. Global APS firms select their location depending on the business that the market capability may supply the opportunities. Just with location at the market center, the firms can control the flow of economic factors to become the center of the world and the nodes of global city network.

This can further explain the findings in literature about the various effects that the different national economies have effectiveness on their cities' connectivity due to their different roles and positions in the global economic system. When the national economic size is small, at the primary period e.g., the primate city connectivity has more benefit from their national economy. Among the case countries of this paper, New Zealand, Hungary, Chile, Singapore, Czechoslovakia, Malaysia, Ireland, Portugal, Thailand, Argentina, Venezuela, Greece, Austria, Sweden, Poland, Belgium, etc. have less than 500 trillion USD in 2010; Hungary, New Zealand, Czechoslovakia, Greece, Vietnam, Portugal, Chile, Ireland, Malaysia, Philippines, United Arab Emirates, Venezuela, Austria, Thailand, Belgium, Poland, etc. have less than 500 trillion USD in 2016. In these countries, the national urban system is strongly vertical link due to the small number of local cities supporting the primate city to connect the world. However, connectivity increases rapidly when the national economy rises. When the national economic size is large, at the second period e.g., the primate city connectivity has low benefit from their national economy. Such countries as USA, China, Japan, German, UK, France, India, Italy, Brazil, Canada, Russia, etc., no matter if inner city connectivity or global city connectivity, have strong horizontal link due to the huge number of cities and the large size of economic development. In these countries, the global city connectivity is growing slowly within the network of the national urban system. Therefore, it can be conducted that the world becomes more curved at its primary stage due to the core economies getting more benefits from the periphery countries through the world cities network, and it will be flatter at the second stage due to the network relations of horizontal linkages.

\section{Conclusions}

This study conducts the relation between the global city connectivity of the primary city and the size of the national economy with specific function. The function illustrates the evolution trajectory of this relation while it combines the national urban system and the global city connectivity together. The conclusion does not only clarify the relation between the world city connectivity and the national economic size, but it also sets up the linkage of the first and the second natures of the city. This linkage can interpreted as the formation of the world city with the combination of two dimensions (vertical and horizontal). 
This study does not just especially provide the explanation about the role of the world city in the 'flowing space' (Castells 1996) as the node of economic flowing, but it further conducts that the connectivity of the world city is determined by the economic size of the hinterland. The result provides empirical evidence supporting the theory that world cities are the function centers of command-and-control located at the sites of production, innovation and markets (Sassen 1991) due to more opportunities close to the bigger market. It further provides an explicit approach to clarify the idea of 'glocal' states which is factually the combination of the global city connectivity and the national urban system.

The relation curve from the model gives the tendency of the relation alteration among the different countries, while the tendency would be reference for the global firms to select the place of the branches with considering the location of the city under the national economic positions in the world and the stages of their global city network in the world system.

The analyses conducted in this study and the conclusions drawn above are based on considering the primary cities only for the selected national economies. It is highly recommended for future investigations to extend the study by including a more inclusive list of global cities. For example, all the world cities within a country can be involved into the connection calculation, and the average value of the cities connectivity within a country will be considered instead for the one of primate city. Then, the result could be more exact. However, the later result will diminish the cities' hierarchy for the national urban system.

Furthermore, with more comprehensive data for cities, future measurements of city interlock connectivity should explore the quantification of both vertical and hierarchical connectivity. In this way, the 'second nature' of a city can be examined not only at the world system scale but also within a hierarchical national or regional urban system structure. 
Relations between Global City Connectivity of the Primary City and the Size National Economy

APS Global firms included in this study

APPENDIX

\begin{tabular}{|c|c|c|}
\hline $\begin{array}{l}\text { \#AB Group Insurance } \\
\text { (China) }\end{array}$ & Commerz bank(Germany) & NKSJ Holdings(japan) \\
\hline \#ACE Group (China) & $\begin{array}{l}\text { Commonwealth Bank of Australia } \\
\text { (Australia) }\end{array}$ & \#Noble Group (China) \\
\hline \#Achmea (The Netherland) & ${ }^{*} \# \mathrm{CPCl}$ (China) & $\begin{array}{l}\text { *\#Nord deutsche Landes bank } \\
\text { (Germany) }\end{array}$ \\
\hline *\#Aegon (The Netherlands) & *\#Credit Suisse (Switzerland) & \# NYSE:HPE (U.S.) \\
\hline \#AFL (U.S) & Dai-ichi Life Insurance(Japan) & \#Old Mutual Corp. (U.K.) \\
\hline $\begin{array}{l}\text { *\#Agricultural Bank of China } \\
\text { (China) }\end{array}$ & Dai Nippon Printing (Japan) & *\#Oracle (U.S.) \\
\hline \#AIA (U.S.) & DanskeBankGroup (Denmark) & \#Orange (France) \\
\hline \#AIG (U.S.) & Deutsche Bank(Germany) & \#PCC (Canada) \\
\hline \#Alibaba Group (China) & *\#Deutsche Telekom (Germany) & \#PICC (China) \\
\hline *\#Allianz (Germany) & *\#DZ Bank (Germany) & Prudential (U.K.) \\
\hline Allstate (U.S.) & \#Exor Group (Italy) & ${ }^{*} \#$ Prudential Financial (U.S.) \\
\hline \#Alphabet (U.S.) & Erste Group Bank(Austria) & \#Poste Italiane (Italy) \\
\hline \#Altice (France) & \#Facebook (U.S.) & *\#Rabo bank (The Netherlands) \\
\hline \#Amazon (U.S.) & France Télécom (France) & Royal Bank of Scotland (U.K.) \\
\hline \#America Movil (Mexico) & \#Generali Group (Italy) & ${ }^{*}$ \#Royal Bank of Canada(Canada) \\
\hline \#Anthem, Inc. (U.S.) & *\#Gold man Sachs Group (U.S.) & $\begin{array}{l}\text { \#Santander Central Hispano S.A. } \\
\text { (Spain) }\end{array}$ \\
\hline \#ANZ Bank (Australia) & \#HSBC (China) & ${ }^{*} \#$ Sber bank (Russia) \\
\hline AssicurazioniGenerali (Italy) & $\begin{array}{l}\text { *\#Industrial \& Commercial Bank } \\
\text { of China(China) }\end{array}$ & \#SG(France) \\
\hline *\#Aviva (U. K) & \#ING (The Netherlands) & ${ }^{\text {*\#Standard Life (U.K.) }}$ \\
\hline AXA (France) & $\begin{array}{l}\text { International Assets Holding } \\
\text { (France) }\end{array}$ & \#Sompo Holdings (Japan) \\
\hline \#AXP (U.S.) & Intesa Sanpaolo (Italy) & \#Sodexo (France) \\
\hline \#Banco Bradesco (Brazil) & \# Itochu Corporation (Japan) & \#Soft Bank (Janpan) \\
\hline Banco do Brasil (Brazil) & \#JD (China) & \#SPD Bank(China) \\
\hline $\begin{array}{l}\text { \#Banco Bilbao Vizcaya Ar- } \\
\text { gentaria (Spain) }\end{array}$ & \#JP.Morgan & State Bank of India (India) \\
\hline *\#Bank of China (China) & *\#KDDI(Japan) & $\begin{array}{l}\text { \#Suning Commerce Group CO., } \\
\text { LTD. (China) }\end{array}$ \\
\hline $\begin{array}{l}\text { Bank of Nova Scotia } \\
\text { (Canada) }\end{array}$ & KFW Bank engruppe (Germany) & $\begin{array}{l}\text { *\#Sumitomo Life Insurance } \\
\text { (Japan) }\end{array}$ \\
\hline Barclays (U.K.) & *\#Legal \& General Group (U.K.) & $\begin{array}{l}\text { *\#Swiss Reinsurance } \\
\text { (Switzerland) }\end{array}$ \\
\hline \#BNP Paribas (France) & $\begin{array}{l}\text { Liberty Mutual Insurance Group } \\
\text { (U.S.) }\end{array}$ & \#Talanx (Germany \\
\hline \#BOCOM (China) & \#LLOYDS (U.K.) & Telstra (Australia) \\
\hline \#Brookfield Asset (Canada) & *\#Manulife Financial (Canada) & \#Tencent (China) \\
\hline *\#BT Group (U.K.) & *\#Mapfre Group (Spain) & \#TIAA-CREF (U.S.) \\
\hline $\begin{array}{l}\text { \#Cathay Insurance Co.,Ltd. } \\
\text { (China) }\end{array}$ & \# Marubeni Corporation (Japan) & \#TMNCH (Japan) \\
\hline \#CEB Bank China) & $\begin{array}{l}\text { *\#Meiji Yasuda Life Insurance } \\
\text { (Japan) }\end{array}$ & Tokio Marine Holdings(Japan) \\
\hline
\end{tabular}


Yongling YAO, Yongmei LU, Gan WANG, Yue DONG, Haowei WANG

\begin{tabular}{|l|l|l|}
\hline $\begin{array}{l}\text { *\#China Construction Bank } \\
\text { (China) }\end{array}$ & $\begin{array}{l}\text { \#Mercantil Servicios Financieros } \\
\text { (Venezuela) }\end{array}$ & \#Toronto-Dominion Bank (Canada) \\
\hline \#China Life (China) & \#Met Life (U.S.) & \#Trafigura Group (The Netherlands) \\
\hline $\begin{array}{l}\text { \#China Merchants Bank } \\
\text { (China) }\end{array}$ & $\begin{array}{l}\text { *\#Mitsubish UFJ Financial } \\
\text { Group (Japan) }\end{array}$ & *\#UBS (Switzerland) \\
\hline \#CHTR (U.S.) & \#Mitsui \& CO., Ltd. (Japan) & \#UniCredit Spa (Italy) \\
\hline \#Cigna (U.S.) & $\begin{array}{l}\text { \#Mizuho Financial Group } \\
\text { (Japan) }\end{array}$ & \#Unicom (China) \\
\hline \#Citic Group (China) & *\#Morgan Stanley (U.S.) & \#United Health (U.S.) \\
\hline *\#Citic Group (U.S.) & *\#Munich Re Group(Germany) & \#US Bancorp (U.S.) \\
\hline \#CMCC (China) & $\begin{array}{l}\text { \#National Australia Bank Ltd. } \\
\text { (Australia) }\end{array}$ & \#Vodafone (U.K.) \\
\hline \#CMBC(China) & \#NCl (China) & Westpac Banking (Australia) \\
\hline \#CNC (U.S.) & *\#Nippon Life Insurance (Japan) & \#Wells Fargo (U.S.) \\
\hline *\#CNP Assurances (France) & $\begin{array}{l}\text { *\#Nippon Telegraph } \\
\text { \&Telephone (Japan) }\end{array}$ & $\begin{array}{l}\text { Zurich Financial Services } \\
\text { (Switzerland) }\end{array}$ \\
\hline
\end{tabular}

Note: (1) () is the name of the firm's host country. (2) * and \# presents the firms used to calculating the interlock connectivity value in 2010 and 2016 respectively.

Estimation results for linear, inverse and exponential functions

APPENDIX $/ /-1$

\begin{tabular}{|c|c|c|c|c|c|c|c|}
\hline \multirow[b]{2}{*}{$\begin{array}{l}\text { Varia- } \\
\text { bles }\end{array}$} & \multirow{2}{*}{ Year } & \multicolumn{2}{|l|}{ GDP } & \multicolumn{2}{|l|}{ GDP/cap } & \multicolumn{2}{|c|}{ GDP-GDP/cap } \\
\hline & & OLS & Bootstrap & OLS & Bootstrap & & \\
\hline \multicolumn{8}{|c|}{ Linear function } \\
\hline \multirow[t]{2}{*}{ gdp } & 2010 & $\begin{array}{l}3.88 \mathrm{e}-05^{\star * *} \\
(5.29 \mathrm{e}-06)\end{array}$ & $\begin{array}{l}3.88 \mathrm{e}-05^{\star * *} \\
(1.01 \mathrm{e}-05)\end{array}$ & & & $\begin{array}{l}3.60 \mathrm{e}-05^{\star * *} \\
(5.02 \mathrm{e}-06)\end{array}$ & $\begin{array}{l}3.60 \mathrm{e}-05^{\star * \star} \\
(9.63 \mathrm{e}-06)\end{array}$ \\
\hline & 2016 & $\begin{array}{l}1.33 e-05^{\star \star \star} \\
(3.43 e-06)\end{array}$ & $\begin{array}{l}1.33 \mathrm{e}-05 \\
(1.14 \mathrm{e}-05)\end{array}$ & & & $\begin{array}{l}1.38 \mathrm{e}-05^{\star \star \star} \\
(3.52 \mathrm{e}-06)\end{array}$ & $\begin{array}{l}1.38 \mathrm{e}-05 \\
(1.19 \mathrm{e}-05) \\
\end{array}$ \\
\hline \multirow[t]{2}{*}{ gdpp } & 2010 & & & $\begin{array}{l}2.74 \mathrm{e}-05^{\star *} \\
(1.05 \mathrm{e}-05)\end{array}$ & $\begin{array}{l}2.74 \mathrm{e}-05^{\star *} \\
(1.16 \mathrm{e}-05)\end{array}$ & $\begin{array}{l}1.70 \mathrm{e}-05^{\star *} \\
(6.73 \mathrm{e}-06)\end{array}$ & $\begin{array}{l}1.70 \mathrm{e}-05^{\star \star *} \\
(6.08 \mathrm{e}-06)\end{array}$ \\
\hline & 2016 & & $\begin{array}{l}2.02 \mathrm{e}-07 \\
(7.17 \mathrm{e}-06)\end{array}$ & $\begin{array}{l}2.02 \mathrm{e}-07 \\
(6.75 \mathrm{e}-06)\end{array}$ & $\begin{array}{l}-4.53 e-06 \\
(6.16 e-06)\end{array}$ & $\begin{array}{l}-4.53 e-06 \\
(4.88 e-06)\end{array}$ & \\
\hline \multirow[t]{2}{*}{ Constant } & 2010 & $\begin{array}{l}0.959^{* * *} \\
(0.154)\end{array}$ & $\begin{array}{l}0.959^{* * *} \\
(0.146)\end{array}$ & $\begin{array}{l}0.758^{* *} \\
(0.353)\end{array}$ & $\begin{array}{l}0.758^{* \star *} \\
(0.217)\end{array}$ & $\begin{array}{l}0.523^{* *} \\
(0.224)\end{array}$ & $\begin{array}{l}0.523^{\star * *} \\
(0.150)\end{array}$ \\
\hline & 2016 & $\begin{array}{l}1.675^{\star \star \star} \\
(0.132)\end{array}$ & $\begin{array}{l}1.675^{\star \star *} \\
(0.145)\end{array}$ & $\begin{array}{l}1.906^{* * *} \\
(0.235)\end{array}$ & $\begin{array}{l}1.906^{\star * *} \\
(0.199) \\
\end{array}$ & $\begin{array}{l}1.786^{\star * \star} \\
(0.201)\end{array}$ & $\begin{array}{l}1.786^{\star * \star} \\
(0.188)\end{array}$ \\
\hline \multirow[t]{2}{*}{$\begin{array}{l}\text { Obser- } \\
\text { vations } \\
\end{array}$} & 2010 & 35 & 35 & 35 & 35 & 35 & 35 \\
\hline & 2016 & 37 & 37 & 37 & 37 & 37 & 37 \\
\hline \multirow[t]{2}{*}{$\begin{array}{l}\text { R- } \\
\text { squared }\end{array}$} & 2010 & 0.620 & 0.620 & 0.172 & 0.172 & 0.683 & 0.683 \\
\hline & 2016 & 0.299 & 0.299 & 0.000 & 0.000 & 0.310 & 0.310 \\
\hline \multicolumn{8}{|c|}{ Inverse function } \\
\hline \multirow[t]{2}{*}{ Ingdp } & 2010 & $\begin{array}{l}-2,436^{\star *} \\
(905.1) \\
\end{array}$ & $\begin{array}{l}-2,436^{\star *} \\
(975.8) \\
\end{array}$ & & & $\begin{array}{l}-2,532^{* * *} \\
(903.0)\end{array}$ & $\begin{array}{l}-2,532^{\star *} \\
(989.4) \\
\end{array}$ \\
\hline & 2016 & $\begin{array}{l}-1,937^{* * *} \\
(660.9)\end{array}$ & $\begin{array}{l}-1,937^{* * *} \\
(723.5)\end{array}$ & & & $\begin{array}{l}-1,953^{* * *} \\
(670.1)\end{array}$ & $\begin{array}{l}-1,953^{* * *} \\
(722.0)\end{array}$ \\
\hline \multirow[t]{2}{*}{ Ingdpp } & 2010 & & & $\begin{array}{l}-1,479 \\
(1,725) \\
\end{array}$ & $\begin{array}{l}-1,479 \\
(3,364) \\
\end{array}$ & $\begin{array}{l}-1,875 \\
(1,576)\end{array}$ & $\begin{array}{l}-1,875 \\
(2,424) \\
\end{array}$ \\
\hline & 2016 & & & $\begin{array}{l}243.1 \\
(1,123) \\
\end{array}$ & $\begin{array}{l}243.1 \\
(989.7) \\
\end{array}$ & $\begin{array}{l}418.3 \\
(1,021) \\
\end{array}$ & $\begin{array}{l}418.3 \\
(964.0) \\
\end{array}$ \\
\hline \multirow[t]{2}{*}{ Constant } & 2010 & $\begin{array}{l}2.115^{\star \star *} \\
(0.294) \\
\end{array}$ & $\begin{array}{l}2.115^{\star * *} \\
(0.367) \\
\end{array}$ & $\begin{array}{l}1.648^{\star * *} \\
(0.258) \\
\end{array}$ & $\begin{array}{l}1.648^{* * *} \\
(0.331) \\
\end{array}$ & $\begin{array}{l}2.297^{\star * *} \\
(0.330) \\
\end{array}$ & $\begin{array}{l}2.297^{\star * \star} \\
(0.455) \\
\end{array}$ \\
\hline & 2016 & $\begin{array}{l}2.326^{\star \star *} \\
(0.189)\end{array}$ & $\begin{array}{l}2.326^{\star \star *} \\
(0.242)\end{array}$ & $\begin{array}{l}1.888^{\star \star *} \\
(0.176)\end{array}$ & $\begin{array}{l}1.888^{\star * *} \\
(0.177)\end{array}$ & $\begin{array}{l}2.289^{\star * *} \\
(0.211)\end{array}$ & $\begin{array}{l}2.289^{\star \star *} \\
(0.258)\end{array}$ \\
\hline
\end{tabular}


Relations between Global City Connectivity of the Primary City and the Size National Economy

\begin{tabular}{|l|l|l|l|l|l|l|l|}
\hline \multirow{2}{*}{$\begin{array}{l}\text { Varia- } \\
\text { bles }\end{array}$} & \multirow{2}{*}{ Year } & \multicolumn{3}{|l|}{ GDP } & \multicolumn{2}{l|}{ GDP/cap } & \multicolumn{2}{l|}{ GDP-GDP/cap } \\
\cline { 3 - 8 } & & OLS & Bootstrap & OLS & Bootstrap & & \\
\hline $\begin{array}{l}\text { Obser- } \\
\text { vations }\end{array}$ & 2010 & 35 & 35 & 35 & 35 & 35 & 35 \\
\hline & 2016 & 37 & 37 & 37 & 37 & 37 & 37 \\
\hline $\begin{array}{l}\text { R- } \\
\text { squared }\end{array}$ & 2010 & 0.180 & 0.180 & 0.022 & 0.022 & 0.215 & 0.215 \\
\hline & 2016 & 0.197 & 0.197 & 0.001 & 0.001 & 0.201 & 0.201 \\
\hline
\end{tabular}

Notes: Standard errors in parentheses. ${ }^{* *} p<0.01,{ }^{* *} p<0.05,{ }^{*} p<0.1$.GDP indicates the estimation with GDP variable only, GDP/cap. indicates the estimation with GDP/cap only, GDP-GDP/cap indicates the estimation with both GDP and GDP/cap together

Estimation results for the quadratic function

APPENDIX II-2

\begin{tabular}{|c|c|c|c|c|c|c|c|}
\hline \multirow{2}{*}{$\begin{array}{l}\text { Varia- } \\
\text { bles }\end{array}$} & \multirow{2}{*}{ Year } & \multicolumn{2}{|l|}{ GDP } & \multicolumn{2}{|l|}{ GDP/cap } & \multicolumn{2}{|c|}{ GDP-GDP/cap } \\
\hline & & OLS & Bootstrap & OLS & Bootstrap & OLS & Bootstrap \\
\hline \multicolumn{8}{|c|}{ Quadratic function } \\
\hline \multirow[t]{2}{*}{ gdp } & 2010 & $\begin{array}{l}3.82 \mathrm{e}-05^{\star *} \\
(1.58 \mathrm{e}-05)\end{array}$ & $\begin{array}{l}3.82 \mathrm{e}-05 \\
(4.47 \mathrm{e}-05) \\
\end{array}$ & & & $\begin{array}{l}3.45 e-05^{\star *} \\
(1.50 e-05)\end{array}$ & $\begin{array}{l}3.45 \mathrm{e}-05 \\
(4.41 \mathrm{e}-05) \\
\end{array}$ \\
\hline & 2016 & $\begin{array}{l}4.47 \mathrm{e}-05^{\star * *} \\
(1.05 \mathrm{e}-05)\end{array}$ & $\begin{array}{l}4.47 e-05^{\star} \\
(2.48 e-05)\end{array}$ & & & $\begin{array}{l}4.57 \mathrm{e}-05^{\star * *} \\
(1.09 \mathrm{e}-05)\end{array}$ & $\begin{array}{l}4.57 e-05^{*} \\
(2.39 e-05)\end{array}$ \\
\hline \multirow[t]{2}{*}{ gdp2 } & 2010 & $\begin{array}{l}0 \\
(1.17 \mathrm{e}-10) \\
\end{array}$ & $\begin{array}{l}0 \\
(1.15 \mathrm{e}-09)\end{array}$ & & & $\begin{array}{l}0 \\
(1.11 \mathrm{e}-10)\end{array}$ & $\begin{array}{l}0 \\
(1.37 \mathrm{e}-09)\end{array}$ \\
\hline & 2016 & $\begin{array}{l}-1.91 \mathrm{e}-10^{* * *} \\
(6.08 \mathrm{e}-11)\end{array}$ & $\begin{array}{l}-1.91 \mathrm{e}-10 \\
(6.24 \mathrm{e}-10)\end{array}$ & & & $\begin{array}{l}-1.95 \mathrm{e}- \\
10^{* * *} \\
(6.34 \mathrm{e}-11)\end{array}$ & $\begin{array}{l}-1.95 e-10 \\
(5.68 e-10)\end{array}$ \\
\hline \multirow[t]{2}{*}{ gdpp } & 2010 & & & $\begin{array}{l}4.31 e-05 \\
(3.63 e-05)\end{array}$ & $\begin{array}{l}4.31 e-05 \\
(4.62 e-05)\end{array}$ & $\begin{array}{l}2.23 e-05 \\
(2.35 e-05)\end{array}$ & $\begin{array}{l}2.23 e-05 \\
(2.83 e-05)\end{array}$ \\
\hline & 2016 & & & $\begin{array}{l}-2.60 \mathrm{e}-06 \\
(2.36 \mathrm{e}-05)\end{array}$ & $\begin{array}{l}-2.60 \mathrm{e}-06 \\
(2.75 \mathrm{e}-05)\end{array}$ & $\begin{array}{l}-1.33 e-05 \\
(1.79 e-05)\end{array}$ & $\begin{array}{l}-1.33 e-05 \\
(2.01 e-05)\end{array}$ \\
\hline \multirow[t]{2}{*}{ gdpp2 } & 2010 & & & $\begin{array}{l}-2.49 \mathrm{e}-10 \\
(5.48 \mathrm{e}-10)\end{array}$ & $\begin{array}{l}-2.49 \mathrm{e}-10 \\
(8.51 \mathrm{e}-10)\end{array}$ & $\begin{array}{l}-8.23 e-11 \\
(3.53 e-10) \\
\end{array}$ & $\begin{array}{l}-8.23 e-11 \\
(4.74 e-10) \\
\end{array}$ \\
\hline & 2016 & & & $\begin{array}{l}0 \\
(3.46 e-10)\end{array}$ & $\begin{array}{l}0 \\
(4.41 \mathrm{e}-10)\end{array}$ & $\begin{array}{l}1.58 \mathrm{e}-10 \\
(2.65 \mathrm{e}-10)\end{array}$ & $\begin{array}{l}1.58 \mathrm{e}-10 \\
(3.21 \mathrm{e}-10) \\
\end{array}$ \\
\hline \multirow[t]{2}{*}{$\begin{array}{l}\text { Cons- } \\
\text { tant } \\
\end{array}$} & 2010 & $\begin{array}{l}0.964^{\star * *} \\
(0.195) \\
\end{array}$ & $\begin{array}{l}0.964^{\star \star \star *} \\
(0.237) \\
\end{array}$ & $\begin{array}{l}0.600 \\
(0.498) \\
\end{array}$ & $\begin{array}{l}0.600 \\
(0.427) \\
\end{array}$ & $\begin{array}{l}0.482 \\
(0.333) \\
\end{array}$ & $\begin{array}{l}0.482 \\
(0.380) \\
\end{array}$ \\
\hline & 2016 & $\begin{array}{l}1.398^{* * *} \\
(0.147) \\
\end{array}$ & $\begin{array}{l}1.398^{* * *} \\
(0.152) \\
\end{array}$ & $\begin{array}{l}1.934^{* * *} \\
(0.324) \\
\end{array}$ & $\begin{array}{l}1.934^{\star * *} \\
(0.309) \\
\end{array}$ & $\begin{array}{l}1.568^{* * *} \\
(0.257) \\
\end{array}$ & $\begin{array}{l}1.568^{\star * *} \\
(0.314) \\
\end{array}$ \\
\hline \multirow[t]{2}{*}{$\begin{array}{l}\text { Obser- } \\
\text { vations }\end{array}$} & 2010 & 35 & 35 & 35 & 35 & 35 & 35 \\
\hline & 2016 & 37 & 37 & 37 & 37 & 37 & 37 \\
\hline \multirow[t]{2}{*}{$\begin{array}{l}\text { R- } \\
\text { squared }\end{array}$} & 2010 & 0.620 & 0.620 & 0.177 & 0.177 & 0.683 & 0.683 \\
\hline & 2016 & 0.456 & 0.456 & 0.000 & 0.000 & 0.468 & 0.468 \\
\hline \multicolumn{8}{|c|}{ Exponential function } \\
\hline \multirow[t]{2}{*}{ gdp } & 2010 & $\begin{array}{l}1.67 \mathrm{e}-05^{* * *} \\
(4.24 \mathrm{e}-06)\end{array}$ & $\begin{array}{l}1.67 e-05^{*} \\
(8.62 e-06)\end{array}$ & & & $\begin{array}{l}1.49 \mathrm{e}-05^{* * *} \\
(4.13 \mathrm{e}-06)\end{array}$ & $\begin{array}{l}1.49 \mathrm{e}-05^{*} \\
(8.44 \mathrm{e}-06)\end{array}$ \\
\hline & 2016 & $\begin{array}{l}5.72 \mathrm{e}-06^{* * *} \\
(1.74 \mathrm{e}-06)\end{array}$ & $\begin{array}{l}5.72 \mathrm{e}-06 \\
(4.75 \mathrm{e}-06)\end{array}$ & & & $\begin{array}{l}5.97 \mathrm{e}-06^{\star * *} \\
(1.79 \mathrm{e}-06)\end{array}$ & $\begin{array}{l}5.97 e-06 \\
(5.22 e-06)\end{array}$ \\
\hline gdpp & 2010 & & & $\begin{array}{l}1.59 \mathrm{e}-05^{* *} \\
(6.32 \mathrm{e}-06)\end{array}$ & $\begin{array}{l}1.59 \mathrm{e}-05^{\star \star *} \\
(5.91 \mathrm{e}-06)\end{array}$ & $\begin{array}{l}1.17 \mathrm{e}-05^{\star *} \\
(5.54 \mathrm{e}-06)\end{array}$ & $\begin{array}{l}1.17 \mathrm{e}-05^{\star \star} \\
(4.84 \mathrm{e}-06)\end{array}$ \\
\hline
\end{tabular}


Yongling YAO, Yongmei LU, Gan WANG, Yue DONG, Haowei WANG

\begin{tabular}{|l|l|l|l|l|l|l|l|}
\hline $\begin{array}{l}\text { Varia- } \\
\text { bles }\end{array}$ & \multirow{2}{*}{ Year } & \multicolumn{2}{|l|}{ GDP } & \multicolumn{2}{l|}{ GDP/cap } & \multicolumn{2}{l|}{ GDP-GDP/cap } \\
\cline { 3 - 8 } & OLS & Bootstrap & OLS & Bootstrap & OLS & Bootstrap \\
\hline & 2016 & & & $\begin{array}{l}-1.55 \mathrm{e}-07 \\
(3.49 \mathrm{e}-06)\end{array}$ & $\begin{array}{l}-1.55 \mathrm{e}-07 \\
(3.17 \mathrm{e}-06)\end{array}$ & $\begin{array}{l}-2.20 \mathrm{e}-06 \\
(3.14 \mathrm{e}-06)\end{array}$ & $\begin{array}{l}-2.20 \mathrm{e}-06 \\
(2.71 \mathrm{e}-06)\end{array}$ \\
\hline $\begin{array}{l}\text { Con- } \\
\text { stant }\end{array}$ & 2010 & $\begin{array}{l}-0.0911 \\
(0.123)\end{array}$ & $\begin{array}{l}-0.0911 \\
(0.142)\end{array}$ & $\begin{array}{l}-0.294 \\
(0.213)\end{array}$ & $\begin{array}{l}-0.294 \\
(0.184)\end{array}$ & $\begin{array}{l}-0.391^{* *} \\
(0.184)\end{array}$ & $\begin{array}{l}-0.391^{* *} \\
(0.177)\end{array}$ \\
\hline & 2016 & $\begin{array}{l}0.464^{* * *} \\
(0.0670)\end{array}$ & $\begin{array}{l}0.464^{* * *} \\
(0.0737)\end{array}$ & $\begin{array}{l}0.570^{* * *} \\
(0.115)\end{array}$ & $\begin{array}{l}0.570^{* * *} \\
(0.103)\end{array}$ & $\begin{array}{l}0.518^{* * *} \\
(0.102)\end{array}$ & $\begin{array}{l}0.518^{* * *} \\
(0.109)\end{array}$ \\
\hline $\begin{array}{l}\text { Obser- } \\
\text { vations }\end{array}$ & 2010 & 35 & 35 & 35 & 35 & 35 & 35 \\
\hline & 2016 & 37 & 37 & 37 & 37 & 37 & 37 \\
\hline $\begin{array}{l}\text { R- } \\
\text { squared }\end{array}$ & 2010 & 0.320 & 0.320 & 0.162 & 0.162 & 0.403 & 0.403 \\
\hline
\end{tabular}

Estimation results for the cubic function

\begin{tabular}{|c|c|c|c|c|c|c|c|}
\hline \multirow[b]{2}{*}{$\begin{array}{l}\text { Varia- } \\
\text { bles }\end{array}$} & \multirow[b]{2}{*}{ Year } & \multicolumn{2}{|l|}{ GDP } & \multicolumn{2}{|l|}{ GDP/cap } & \multicolumn{2}{|c|}{ GDP-GDP/cap } \\
\hline & & OLS & Bootstrap & OLS & Bootstrap & OLS & Bootstrap \\
\hline \multirow[t]{2}{*}{ gdp } & 2010 & $\begin{array}{l}0.000112^{* * *} \\
(4.08 \mathrm{e}-05)\end{array}$ & $\begin{array}{l}0.000112 \\
(0.000115) \\
\end{array}$ & & & $\begin{array}{l}9.52 \mathrm{e}-05^{\star *} \\
(4.03 \mathrm{e}-05)\end{array}$ & $\begin{array}{l}9.52 \mathrm{e}-05 \\
(0.000122)\end{array}$ \\
\hline & 2016 & $\begin{array}{l}4.87 e-05^{\star *} \\
(1.95 e-05)\end{array}$ & $\begin{array}{l}4.87 e-05 \\
(7.03 e-05)\end{array}$ & & & $\begin{array}{l}5.22 \mathrm{e}-05^{\star *} \\
(2.12 \mathrm{e}-05)\end{array}$ & $\begin{array}{l}5.22 e-05 \\
(8.02 e-05)\end{array}$ \\
\hline \multirow[t]{2}{*}{ gdp2 } & 2010 & $\begin{array}{l}-2.21 \mathrm{e}-09^{*} \\
(1.14 \mathrm{e}-09)\end{array}$ & $\begin{array}{l}-2.21 \mathrm{e}-09 \\
(8.12 \mathrm{e}-09) \\
\end{array}$ & & & $\begin{array}{l}-1.85 \mathrm{e}-09 \\
(1.11 \mathrm{e}-09) \\
\end{array}$ & $\begin{array}{l}-1.85 \mathrm{e}-09 \\
(8.72 \mathrm{e}-09) \\
\end{array}$ \\
\hline & 2016 & $\begin{array}{l}-2.68 \mathrm{e}-10 \\
(3.26 \mathrm{e}-10)\end{array}$ & $\begin{array}{l}-2.68 \mathrm{e}-10 \\
(5.44 \mathrm{e}-09)\end{array}$ & & & $\begin{array}{l}-3.28 \mathrm{e}-10 \\
(3.54 \mathrm{e}-10)\end{array}$ & $\begin{array}{l}-3.28 \mathrm{e}-10 \\
(6.03 e-09)\end{array}$ \\
\hline \multirow[t]{2}{*}{ gdp3 } & 2010 & $\begin{array}{l}0^{*} \\
(0)\end{array}$ & $\begin{array}{l}0 \\
(0) \\
\end{array}$ & & & $\begin{array}{l}0 \\
(0)\end{array}$ & $\begin{array}{l}0 \\
(0) \\
\end{array}$ \\
\hline & 2016 & $\begin{array}{l}0 \\
(0) \\
\end{array}$ & $\begin{array}{l}0 \\
(0) \\
\end{array}$ & & & $\begin{array}{l}0 \\
(0) \\
\end{array}$ & $\begin{array}{l}0 \\
(0) \\
\end{array}$ \\
\hline \multirow[t]{2}{*}{ gdpp } & 2010 & & & $\begin{array}{l}-9.91 \mathrm{e}-05 \\
(9.41 \mathrm{e}-05)\end{array}$ & $\begin{array}{l}-9.91 e-05 \\
(0.000131)\end{array}$ & $\begin{array}{l}-1.45 \mathrm{e}-05 \\
(6.25 \mathrm{e}-05)\end{array}$ & $\begin{array}{l}-1.45 e-05 \\
(0.000126) \\
\end{array}$ \\
\hline & 2016 & & & $\begin{array}{l}-7.42 \mathrm{e}-05 \\
(6.27 \mathrm{e}-05) \\
\end{array}$ & $\begin{array}{l}-7.42 \mathrm{e}-05 \\
(5.67 \mathrm{e}-05) \\
\end{array}$ & $\begin{array}{l}-4.61 e-05 \\
(5.00 e-05) \\
\end{array}$ & $\begin{array}{l}-4.61 \mathrm{e}-05 \\
(4.31 \mathrm{e}-05) \\
\end{array}$ \\
\hline \multirow[t]{2}{*}{ gdpp2 } & 2010 & & & $\begin{array}{l}4.32 \mathrm{e}-09 \\
(2.86 \mathrm{e}-09) \\
\end{array}$ & $\begin{array}{l}4.32 \mathrm{e}-09 \\
(5.94 \mathrm{e}-09) \\
\end{array}$ & $\begin{array}{l}1.02 e-09 \\
(1.93 e-09)\end{array}$ & $\begin{array}{l}1.02 \mathrm{e}-09 \\
(5.72 \mathrm{e}-09) \\
\end{array}$ \\
\hline & 2016 & & & $\begin{array}{l}2.40 \mathrm{e}-09 \\
(1.94 \mathrm{e}-09)\end{array}$ & $\begin{array}{l}2.40 \mathrm{e}-09 \\
(2.19 \mathrm{e}-09)\end{array}$ & $\begin{array}{l}1.20 \mathrm{e}-09 \\
(1.57 \mathrm{e}-09)\end{array}$ & $\begin{array}{l}1.20 \mathrm{e}-09 \\
(1.52 \mathrm{e}-09)\end{array}$ \\
\hline \multirow[t]{2}{*}{ gdpp3 } & 2010 & & & $\begin{array}{l}-0 \\
(0) \\
\end{array}$ & $\begin{array}{l}-0 \\
(0) \\
\end{array}$ & $\begin{array}{l}-0 \\
(0) \\
\end{array}$ & $\begin{array}{l}-0 \\
(0) \\
\end{array}$ \\
\hline & 2016 & & & $\begin{array}{l}-0 \\
(0) \\
\end{array}$ & $\begin{array}{l}-0 \\
(0) \\
\end{array}$ & $\begin{array}{l}-0 \\
(0) \\
\end{array}$ & $\begin{array}{l}-0 \\
(0) \\
\end{array}$ \\
\hline \multirow[t]{2}{*}{$\begin{array}{l}\text { Cons- } \\
\text { tant }\end{array}$} & 2010 & $\begin{array}{l}0.643^{* *} \\
(0.249) \\
\end{array}$ & $\begin{array}{l}0.643^{*} \\
(0.349) \\
\end{array}$ & $\begin{array}{l}1.512^{*} \\
(0.742) \\
\end{array}$ & $\begin{array}{l}1.512^{* *} \\
(0.731) \\
\end{array}$ & $\begin{array}{l}0.499 \\
(0.537) \\
\end{array}$ & $\begin{array}{l}0.499 \\
(0.896) \\
\end{array}$ \\
\hline & 2016 & $\begin{array}{l}1.374^{* * *} \\
(0.179) \\
\end{array}$ & $\begin{array}{l}1.374^{* * *} \\
(0.229) \\
\end{array}$ & $\begin{array}{l}2.362^{* * *} \\
(0.474) \\
\end{array}$ & $\begin{array}{l}2.362^{* * *} \\
(0.414) \\
\end{array}$ & $\begin{array}{l}1.742^{* * *} \\
(0.396) \\
\end{array}$ & $\begin{array}{l}1.742^{* * *} \\
(0.463) \\
\end{array}$ \\
\hline \multirow[t]{2}{*}{$\begin{array}{l}\text { Observa- } \\
\text { tions }\end{array}$} & 2010 & 35 & 35 & 35 & 35 & 35 & 35 \\
\hline & 2016 & 37 & 37 & 37 & 37 & 37 & 37 \\
\hline \multirow[t]{2}{*}{$\begin{array}{l}\text { R- } \\
\text { squared }\end{array}$} & 2010 & 0.661 & 0.661 & 0.242 & 0.242 & 0.717 & 0.717 \\
\hline & 2016 & 0.457 & 0.457 & 0.044 & 0.044 & 0.479 & 0.479 \\
\hline
\end{tabular}




\section{Acknowledgement}

Supported by the Research Funds of Renmin University of China "The model of symbiosis of urban system within total domain" (No. 18XNLY01)

\section{References}

AHARONI Y., NACHUM L. (eds.) (2000), Globalisation of Services: Some Implications for Theory and Practice, Routledge, London.

ALDERSON A. S., BECKFIELD J., SPRAGUE-JONES J. (2010), Intercity relations and globalisation: the evolution of the global urban hierarchy, 1981-2007, Urban Studies 47 (9), 1899-1923.

BEAVERSTOCK J. V., SMITH R. G., TAYLOR P. J. (2000), World-city network: a new metageography?, Annals of the Association of American Geographers 90 (1),123-134.

BELDERBOS R., DU H. S., GOERZEN A. (2017), Global Cities, Connectivity, and the Location Choice of MNC Regional Headquarters, Journal of Management Studies 54 (8), 1271 1302.

BOUSSEBAA M. (2009), Struggling to organize across national borders: The case of global resource management in professional service firms, Human Relations 62 (6), 829-850.

BRENNER N. (1998), Global cities, glocal states: global city formation and state territorial restructuring in contemporary Europe, Review of International Political Economy 5 (1), 1-37. 73-102.

CABIGON J. V. (2006), Cities in Globalization, Asia-Pacific Social Science Review 6 (2),

CASTELLS M. (1996), The Rise of Network Society (2nd ed.), Blackwell, Oxford.

CHOI J. H., BARNETT G. A., CHON B.-S. (2006), Comparing world city networks: a network analysis of Internet backbone and air transport intercity linkages, Global Networks 6 (1), 81-99.

DEMPSEY K. E. (2016), Competing claims and nationalist narratives: a city/state debate in a globalising world, Journal of Economic \& Social Geography 107 (1), 33-47.

DERUDDER B., TAYLOR P. J. (2017), Central flow theory: Comparative connectivities in the world-city network, Regional Studies, DOI: 10.1080/00343404.2017.1330538.

DERUDDER B., TAYLOR P., NI P., DE VOS A., HOYLER M., HANSSENS H., BASSENS D., HUANG J., WITLOX F., SHEN W., YANG X. (2010), Pathways of Change: Shifting Connectivities in the World City Network, 2000-08, Urban Studies 47 (9), 1861-1877.

DERUDDER B., TAYLOR P. J., WITLOX F., CATALANO G. (2003), Hierarchical Tendencies and Regional Patterns in the World City Network: A Global Urban Analysis of 234 Cities, Regional Studies 37 (9), 875-886.

DERUDDER B., WITLOX F. (2005), An appraisal of the use of airline data in assessing the world city network: a research note on data, Urban Studies 42 (13), 2371-2388.

DERUDDER B., WITLOX F. (2008), Mapping world city networks through airline flows: context, relevance, and problems, Journal of Transport Geography 16 (5), 305-312.

FAULCONBRIDGE J. (2007), Global shift. Mapping the changing contours of the world economy (5th edition). Peter Dicken, Journal of Economic Geography 7 (6), 777-779. 69-83.

FRIEDMANN J. (1986), The world city hypothesis, Development and Change, 17 (1)

GOTTMAN J. (1989), What are cities becoming centers of? Sorting out the possibilities, in: Knight R. V., Gappert G. (eds.), Cities in a Global Society, Sage, Newbury Park, CA, pp. 5867.

GRUBESIC T. H., MATISZIW T. C., ZOOK M. A. (2009), Spatio-temporal fluctuations in the global airport hierarchies, Journal of Transport Geography 17 (4), 264-275. 
HARRINGTON J. W., DANIELS P. W. (eds.) (2006), Knowledge-based Services, Internationalization and Regional Development, Routledge, Ashgate.

HERMELIN B. (2009), Producer service firms in globalising cities: the example of advertising firms in Stockholm, The Service Industries Journal 29 (4), 457-471.

JACOBS J. (1984), Cities and the Wealth of Nations: principles of economic life, Random House, New York.

JACOBS J. (1992), Systems of Survival: A dialogue on the moral foundations of commerce and politics, Random House, New York.

JACOBS W., KOSTER H., HALL P. (2011), The location and global network structure of maritime advanced producer services, Urban Studies 48 (13), 2749-2769.

KEELING D. J. (1995), Transportation and the world city paradigm, in: Knox P. L., Taylor P. J. (eds.), World Cities in a World-system, Cambridge University Press, Cambridge, pp. 115131.

MA X., TIMBERLAKE M. (2013), World city typologies and national city system deterritorialisation: USA, China and Japan, Urban Studies 50 (2), 255-275.

MAHUTGA M. C., MA X., SMITH D. A., TIMBERLAKE M. (2010), Economic Globalisation and the Structure of the World City System: The Case of Airline Passenger Data, Urban Studies 47 (9), 1925-1947.

MALECKI E. J. (2002), The economic geography of the internet's infrastructure, Economic Geography 78 (4), 399-424.

MATSUMOTO H. (2004), International urban systems and air passenger and cargo flows: some calculations, Journal of Air Transport Management 10 (4), 239-247.

MEIJERS E. J., BURGER M. J., HOOGERBRUGGE M. M. (2016), Borrowing size in networks of cities: City size, network connectivity and metropolitan functions in Europe, Papers in Regional Science 95 (1), 181-198.

MOSS M. L., TOWNSEND A. M. (2000), The Internet backbone and the American metropolis, The Information Society 16 (1), 35-47.

MUSIL R. (2013), World Cities in a System of Nation States, GaWC Research Bulletin

MUSIL R. (2014), European Global Cities in the Recent Economic Crisis, Tijdschrift voor Economische en Sociale Geografie 105 (4), 492-503.

O'CONNOR K. (2003), Global air travel: toward concentration or dispersal?, Journal of Transport Geography 11 (2), 83-92.

ORDÓÑEZ J. A. C., GARCÍA C. G. (2010), Latin American cities and globalisation: change and permanency in the context of development expectations, Urban Studies 47 (9), 2003-2021.

PARNREITER C. (2014), Network or hierarchical relations? A plea for redirecting attention to the control functions of global cities, Tijdschrift voor Economische en Sociale Geografie 105 (4), 398-411.

PFLIEGER G., ROZENBLAT C. (2010), Introduction. Urban networks and network theory: the city as the connector of multiple networks, Urban Studies 47 (13), 2723-2735.

PIRIE G. (2010), Trajectories of North-South city inter-relations: Johannesburg and Cape Town, 1994-2007, Urban Studies 47 (9), 1985-2002.

RAŹNIAK P., WINIARCZYK-RAŹNIAK A., NOWOTNIK D. (2015), Central and Eastern European cities in globalized world, Socio-Economic Problems and the State 12 (1), 22-33.

RIMMER P. J. (1998), Transport and telecommunications among world cities, in: Lo F.C., Yeung Y.-M. (eds.), Globalization and the World of Large Cities, United Nations University Press, Tokyo, pp. 433-470.

SASSEN S. (1991), The Global City, Princeton University Press, Princeton, NJ.

SHORT J. R. (2017), Global Cities, in: Richardson D., Castree N., Goodchild M. F., Kobayashi A., Liu W., Marston R. A., International Encyclopedia of Geography: People, the Earth, Environment and Technology, Wiley-Blackwell, Chichester, UK.

SMITH D. A., TIMBERLAKE M. (1995), Conceptualising and mapping the structure of 
the world system's city system, Urban Studies 32 (2), 287-302.

SMITH D. A., TIMBERLAKE M. F. (2001), World city networks and hierarchies, 19771997. An Empirical Analysis of Global Air Travel Links, American Behavioral Scientist 44 (10), 1656-1678.

SMITH D., TIMBERLAKE M. (2002), Hierarchies of dominance among world cities: a network approach, in: Sassen S. (ed.), Global Networks. Linked Cities, Routledge, London, pp.117-141.

SMITH R. G. (2014), Beyond the Global City Concept and the Myth of 'Command and Control', International Journal of Urban and Regional Research 38 (1), 98-115.

TAYLOR P. J. (2002), Amsterdam in a World City Network, GAWC Research Report, Loughborough.

TAYLOR P. J. (2014), A Research Odyssey: from Interlocking Network Model to Extraordinary Cities, Tijdschrift voor Economische en Sociale Geografie 105 (4), 387-397.

TAYLOR P. J., ARANYA R. (2008), A global 'urban roller coaster'? Connectivity changes in the world city network, 2000-2004, Regional Studies 42 (1), 1-16.

TAYLOR P. J., DERUDDER B. (2016), World City Network: A global urban analysis, 2nd Edition, Routledge, London.

TAYLOR P., DERUDDER B., HOYLER M., NI P., WITLOX F. (2014), City-dyad Analyses of China's integration into the world city network, Urban Studies 51 (5), 868-882.

THERBORN G. (2011), End of a paradigm: The current crisis and the idea of stateless cities, Environment and Planning A: Economy and Space 43 (2), 272-285.

TIMBERLAKE M., SANDERSON M. R., MA X., DERUDDER B., WINITZKY J., WITLOX F. (2012), Testing a Global City Hypothesis: An Assessment of Polarization across US Cities, City \& Community 11 (1), 74-93.

TOWNSEND A. M. (2001a), Network cities and the global structure of the Internet, American Behavioral Scientist 44 (10), 1697-1716.

TOWNSEND A. M. (2001b), The Internet and the rise of the new network cities, 19691999, Environment and Planning B: Urban Analytics and City Science 28 (1), 39-58.

VAN OORT F., BURGER M., RASPE O. (2010), On the economic foundation of the urban network paradigm: spatial integration, functional integration and economic complementarities within the Dutch Randstad, Urban Studies 47 (4), 725-748.

Initial submission: 18.07.2017

Revised submission: 11.04 .2018

Final acceptance: 07.05.2018

Correspondence: School of Economics, Renmin University of China, Zhongguancun Street 59, Haidian District, Beijing 100872, China.

Email: yaoyongling@ruc.edu.cn 
